Original article

\title{
Distribution of HBV genotypes in Poland
}

\author{
Magdalena Świderska', Małgorzata Pawłowska², Włodzimierz Mazur³, Krzysztof Tomasiewicz', Krzysztof Simon5, \\ Anna Piekarska ${ }^{6}$, Marta Wawrzynowicz-Syczewskaa ${ }^{7}$, Jerzy Jaroszewicz' ${ }^{1}$ Paweł Rajewski², Ewelina Zasik3 \\ Elżbieta Murias-Bryłowska ${ }^{4}$, Anna Pniewska² ${ }^{2}$ Waldemar Halota², Robert Flisiak ${ }^{1}$ \\ ${ }^{1}$ Klinika Chorób Zakaźnych i Hepatologii, Uniwersytet Medyczny w Białymstoku, Białystok, Poland \\ ${ }^{2}$ Katedra Chorób Zakaźnych i Hepatologii, Collegium Medicum w Bydgoszczy, Uniwersytet Mikołaja Kopernika w Toruniu, Poland \\ ${ }^{3}$ Kliniczny Oddział Obserwacyjno-Zakaźny, Śląski Uniwersytet Medyczny w Katowicach, Katowice, Poland \\ ${ }^{4}$ Katedra i Klinika Chorób Zakaźnych, Uniwersytet Medyczny w Lublinie, Lublin, Poland \\ ${ }^{5}$ Zakład Chorób Zakaźnych i Hepatologii, Uniwersytet Medyczny we Wrocławiu, Wrocław, Poland \\ ${ }^{6}$ Klinika Chorób Zakaźnych i Hepatologii, Uniwersytet Medyczny w Łodzi, Łódź, Poland \\ ${ }^{7}$ Klinika Chorób Zakaźnych, Hepatologii i Transplantacji Wątroby, Pomorski Uniwersytet Medyczny w Szczecinie, Szczecin, Poland
}

\begin{abstract}
Aim of the study: To identify distribution of HBV genotypes in particular regions of Poland.

Material and methods: The study included 270 treatment-naïve, HBV-infected individuals, enrolled in 7 centers of Poland. HBV genotyping was performed in 243 of them with the INNO-LiPA HBV Genotyping assay (Innogenetics).

Results: Genotype A present in 2/3 patients was demonstrated as the most predominant in Poland. It was followed by D (20\%), H (5\%) and mixed A + D (5\%). Remaining patients were infected with genotype F, mixed $D+G, A+C$ or $D+F$. Analysis of distribution demonstrated regional differences, with a higher rate of genotype $D$ prevalence (about 30\%) in the eastern (Białystok and Lublin) and south-western (Wroctaw) parts compared to other regions, where the prevalence rate was below 15\%. The highest prevalence of genotype A (exceeding $80 \%$ ) was observed in central Poland (Bydgoszcz, tódź).

Conclusions: The presented data reveal the current distribution of HBV genotypes across Poland, which is the first and the largest such epidemiological analysis.
\end{abstract}

Key words: HBV, epidemiology, hepatitis, genotypes.

\section{Address for correspondence}

Robert Flisiak, Department of Infectious Diseases and Hepatology, Medical University of Bialystok, 14 Żurawia St., 15-540 Bialystok, Poland, e-mail: robert.flisiak@umb.edu.pl

\section{Introduction}

Infection with hepatitis B virus (HBV) remains a huge public health issue all over the world [1]. A third of the world population, which is approximately 2 billion people, reveals serologic infections with HBV in the past or currently [1]. It is estimated that approximately 1 million people per year die due to acute and chronic infections with HBV. A few viral factors exist which may influence infections with HBV including HBV DNA genotype and mutations in surface $\mathrm{HBV}(\mathrm{S})$, precore (PC) and basic core promoter (BCP) [2].
One feature of HBV is sequence heterogeneity of the virus caused by the lack of polymerase activity [1].

Analysis of HBV sequence divergence enables identification of 10 genotypes of HBV (A-J) and a few subgenotypes noted worldwide $[3,4]$. No subgenotypes for genotypes $\mathrm{E}$ and $\mathrm{G}$ have been described $[5,6]$. HBV genotypes are differently allocated geographically, which may indicate the way of HBV spreading. Genotype A (HBV-A) is common in Sub-Saharan Africa (subgenotype A1), Northern Europe (subgenotype A2), Western Africa (subgenotype A3) and in northern Italy (Table 1 ) $[2,7,8]$. Genotypes B and C are 
Table 1. Characteristics of patients included in the study

\begin{tabular}{lc}
\hline Gender, M/F (\%) & $140 / 130(52 / 48)$ \\
\hline Age, median years (range) & $35(25-43)$ \\
\hline HBeAg-positive, $\boldsymbol{n}(\%)$ & $14(5)$ \\
\hline ALT > ULN, $\boldsymbol{n}(\%)$ & $66(24)$ \\
\hline ALT, median IU/mI (IQR) & $28(20-40)$ \\
\hline HBV DNA > 2000 IU/ml, $\boldsymbol{n}(\%)$ & $141(52)$ \\
\hline HBsAg, median IU/ml (IQR) & $13436(3744-23$ 134) \\
\hline Liver fibrosis, $\boldsymbol{n} / \mathbf{N}>$ F1 (\%) & $33 / 184(18)$ \\
\hline ALT - alanine aminotransferase, ULN - upper limit of normal
\end{tabular}

common in Asia and in the Pacific region. However, the indicators of genotypes $\mathrm{B}$ and $\mathrm{C}$ occurrence differ between different Asian countries. HBV-C occurs more frequently than HBV-B in China, Japan and Korea and HBV-B is more frequent in Taiwan and Vietnam $[2,7,8]$. What is worth mentioning is the fact that almost every patient with chronic hepatitis B in Korea is infected with HBV-C. Genotype D is frequently seen in patients with HBV in Southern and Eastern Europe. According to WHO classification, genotype D is the most common in Iran $[3,7,9]$.

Infections with other genotypes are rare, but their epidemiology has been characterized widely $[7,9]$. Genotypes E and F were discovered in Western Africa, Southern USA, Central and Southern America as well as Central Europe [5]. HBV genotype E occurs in Western Africa. Genotype F is commonly seen in Central and Southern America, especially in Buenos Aires, Argentina [10]. The case of Rosario city seems to be interesting due to the fact that although it is located 150 miles north of Buenos Aires, the most common genotype there is $\mathrm{A}$, which is probably connected with the large number of Italian immigrants [11]. Genotype $G$ has been observed in France, Germany and United States. Genotype $\mathrm{H}$ is seen in Central America. Two additional genotypes have been identified recently: genotype I in Laos and Vietnam and genotype J in Ryukyu Island, Japan $[3,4,9]$. Up to now, studies which evaluated HBV genotypes in Poland were carried out about 10 years ago, based on the data from one center, and included a relatively small number of patients $[12,13]$. There has been no study that involved a sufficient number of patients to perform analysis on genotypes' regional distribution.

The EpiGeneS study was designed for a long-term cohort analysis of an effect of baseline host and viral factors associated with chronic HBV infection on disease progression and treatment efficacy.

The aim of the EpiGeneS study at this stage was to identify prevalence of particular HBV genotypes and possible regional distribution differences in Poland, as the baseline characteristics of the studied population.

\section{Material and methods}

In this multicenter, cross-sectional study, 270 treatment-naïve individuals with persistent HBV infection were initially enrolled in 7 university centers in Poland (2013-2014). Inclusion criteria were not restricted by hepatitis $\mathrm{B}$ e antigen ( $\mathrm{HBeAg}$ ) status, alanine aminotransferase (ALT) activity or HBV-DNA. However, viral load should be on the level allowing for genotype quantification. Exclusion criteria were: hepatitis $\mathrm{C}$ (HCV), human immunodeficiency (HIV) and hepatitis D (HDV) viral co-infections, previous anti-HBV therapy, autoimmune disorders, neoplastic disorders and immunotherapy. HBV genotyping was performed in 243 persons who demonstrated a sufficient HBVDNA level with the INNO-LiPA HBV Genotyping assay (Innogenetics) by the central laboratory for all involved centers (Synevo). All participants signed informed consent and this study was approved by the Ethical Committee of the Medical University of Bialystok. The procedures followed were in accordance with the Helsinki Declaration of 1975, as revised in 2000.

\section{Results}

As demonstrated in Table 1, the majority of patients included in the study were relatively young. The large majority of them were $\mathrm{HBeAg}$-negative, and demonstrated normal ALT activity and a low stage of liver fibrosis. More than half showed HBV DNA exceeding $2000 \mathrm{IU} / \mathrm{ml}$ and all had hepatitis B s antigen (HBsAg) above $3700 \mathrm{IU} / \mathrm{ml}$.

According to data in Table 2, the most predominant genotype in Poland is $\mathrm{A}$, confirmed in $2 / 3$ of patients included in the study. The second is $\mathrm{D}$ followed by genotype $\mathrm{H}$ and mixed $\mathrm{A}+\mathrm{D}$. The remaining $2 \%$ consisted of 1 patient with genotype $\mathrm{F}$ and mixed genotypes $\mathrm{D}+\mathrm{G}$ (3 patients), $\mathrm{A}+\mathrm{C}$ (1 patient) or $\mathrm{D}+\mathrm{F}$ (1 patient). Altogether $92 \%$ of Polish patients were infected with genotype A or D. However, collected data demonstrated differences in genotype distribution between particular regions of the country, with a higher rate of genotype D prevalence (about 30\%) in the eastern part (Białystok and Lublin) and south-western part (Wrocław) compared to other centers where the prevalence rate was below $15 \%$. The highest prevalence rate of genotype A, exceeding $80 \%$, was observed in central Poland (Bydgoszcz, Łódź). 
Table 2. Prevalence of HBV genotypes in selected regions of Poland

\begin{tabular}{ccccccccc}
\hline & Białystok & Lublin & tódź & Wrocław & Szczecin & Chorzów & Bydgoszcz & Poland \\
\hline A & $32(48 \%)$ & $12(57 \%)$ & $6(86 \%)$ & $17(59 \%)$ & $3(75 \%)$ & $23(77 \%)$ & $71(83 \%)$ & $164(67 \%)$ \\
\hline D & $18(27 \%)$ & $7(33 \%)$ & $1(14 \%)$ & $8(28 \%)$ & 0 & $2(7 \%)$ & $12(14 \%)$ & $48(20 \%)$ \\
\hline H & $7(11 \%)$ & $1(5 \%)$ & 0 & $1(3 \%)$ & $1(25 \%)$ & $1(3 \%)$ & $2(2 \%)$ & $13(5 \%)$ \\
\hline A + D & $7(11 \%)$ & 0 & 0 & $2(7 \%)$ & 0 & $3(10 \%)$ & 0 & $12(5 \%)$ \\
\hline Other & $2(3 \%)$ & $1(5 \%)$ & 0 & $1(3 \%)$ & 0 & $1(3 \%)$ & $1(1 \%)$ & $6(2 \%)$ \\
\hline & 66 & 21 & 7 & 29 & 4 & 30 & 86 & 243 \\
\hline
\end{tabular}

\section{Discussion}

In Poland, over $1500 \mathrm{HBV}$ infections per year are diagnosed, and the number of infected patients is estimated to be between 400 and 600 thousand. The estimated number of HBV carriers (HBsAg-positive) is $1.3 \%$ of the population [14]. In reports published so far in Poland, genotypes A and D are predominant. Zalewska et al. [12] discovered genotype A in $78.8 \%$ of HBV carriers and in $13.6 \%$ it was genotype D. Slusarczyk et al. confirmed predominance of genotype A, which was discovered in 56 of 65 patients (86.1\%). Genotype D was demonstrated in $6(9.2 \%)$ and $\mathrm{A}+\mathrm{D}$ in $3(4.6 \%)$ [13]. The multicenter EpiGeneS study which started in 2013 included a large group of treatment-naïve patients, who will be followed for possible associations between treatment type, viral genotypes, HBsAg levels, course of the disease and other possible predictors of treatment efficacy. At the current stage 270 patients have been included and samples collected from the majority of them allowed analysis of HBV genotype distribution in Poland to be performed.

The study confirmed predominance of genotype A in all regions of Poland, with the highest rate in the central part of the country. Data from Bydgoszcz and Łódź demonstrating a rate exceeding $80 \%$ are in line with previous data from Warsaw [13]. In addition, we were able to show geographical differences in distribution of genotype $\mathrm{D}$, which seems to be more frequently seen in patients from eastern (Białystok, Lublin) and south-western (Wrocław) than in other regions of Poland, which was never demonstrated in the past.

In $17(7 \%)$ patients we were not able to demonstrate one genotype responsible for $\mathrm{HBV}$ infection, possibly suggesting damage of adaptive immunity in these cases, which will be interesting with respect to future follow-up of these patients and the possible effect of treatment [5].

The type of HBV genotype may significantly influence the risk of hepatocellular carcinoma (HCC) development and progression of the disease [5]. It was demonstrated that genotypes A, B and D are associated with lower risk of hepatocellular carcinoma compared to genotype $C[15,16]$, but patients infected with genotype $\mathrm{C}$ and $\mathrm{D}$ reveal higher risk of progression of the disease which may be related to worse clinical prognosis in comparison to patients with genotype A and B $[1,7]$. However, there are also reports of studies which did not demonstrate any association between $\mathrm{HBV}$ genotypes and risk of HCC [17]. Discrepancies between those results, especially derived from the same regions, are not clear [1]. Moreover, genotype $\mathrm{C}$ in comparison to genotype $\mathrm{B}$ is associated with a higher frequency of core promoter mutation and a lower rate of response to interferon alpha treatment [5]. A study conducted in Alaska which included 1536 patients, after 20 years of follow-up revealed higher risk of HCC in patients infected with genotypes $C$ and $F$ [18].

It was demonstrated in several studies that genotype A infected patients respond better to treatment with IFN- $\alpha$ than those infected with genotype $D$, which has significant implications for the choice of treatment in Poland. On the other hand, there are no clear data on the association between HBV genotype and treatment response to nucleos(t)ide analogues as well as risk of resistance [5,19-21]. Therefore long-term follow-up of patients included in an EpiGeneS cohort will be of value when they start different treatment options.

In conclusion, the presented data reveal the current distribution of HBV genotypes across Poland, which is the first and the largest such epidemiological analysis. The well-characterized population of treatment naïve patients expecting possible therapy can serve as an excellent cohort for the further analysis of an effect of HBV genotypes and some other baseline factors on natural history of HBV infection and treatment efficacy with different therapeutic options.

\section{Disclosure}

Authors report no conflict of interest. 


\section{References}

1. Chen QY, Harrison TJ, Sabin CA, et al. The Effect of HBV Genotype $\mathrm{C}$ on the Development of HCC Differs Between WildType Viruses and Those With BCP Double Mutations (T(1762) A(1764)). Hepat Mon 2014; 14: e16214.

2. Sali S, Alavian SM, Foster GR, et al. Influencing Factors on the Outcome and Prognosis of Patients With HBV Infection: Seven Years Follow-up. Hepat Mon 2013; 13: e8743.

3. Congly SE, Wong P, Al-Busafi SA, et al. Characterization of hepatitis $B$ virus genotypes and quantitative hepatitis B surface antigen titres in North American tertiary referral liver centres. Liver Int 2013; 33: 1363-1369.

4. Awan Z, Idrees M, Amin I, et al. Pattern and molecular epidemiology of Hepatitis B virus genotypes circulating in Pakistan. Infect Genet Evol 2010; 10: 1242-1246.

5. Bessone F. Re-appraisal of old and new diagnostic tools in the current management of chronic hepatitis B. Liver Int 2014; 34: 991-1000.

6. Pourkarim MR, Amini-Bavil-Olyaee S, Lemey P, et al. Are hepatitis B virus "subgenotypes" defined accurately? J Clin Virol 2010; 47: 356-360.

7. Zhang Q, Cao G. Genotypes, mutations, and viral load of hepatitis $B$ virus and the risk of hepatocellular carcinoma: HBV properties and hepatocarcinogenesis. Hepat Mon 2011; 11: 86-91.

8. Raimondi S, Maisonneuve P, Bruno S, et al. Is response to antiviral treatment influenced by hepatitis B virus genotype? J Hepatol 2010; 52: 441-449.

9. Cheng Y, Guindon S, Rodrigo A, et al. Cumulative viral evolutionary changes in chronic hepatitis $B$ virus infection precedes hepatitis B e antigen seroconversion. Gut 2013; 62: 1347-1355.

10. Pezzano SC, Torres C, Fainboim HA, et al. Hepatitis B virus in Buenos Aires, Argentina: genotypes, virological characteristics and clinical outcomes. Clin Microbiol Infect 2011; 17: 223-231.

11. Bessone F, Fay F, Benetti S, et al. High prevalence of genotype A in patients with chronic hepatitis B in Rosario, Argentina. Ann Hepatol 2008; 7: 265.

12. Zalewska M, Domagała M, Simon K, et al. Hepatitis B virus genotypes and the response to lamivudine therapy. Pol Arch Med Wewn 2005; 114: 1190-1199.

13. Slusarczyk J, Białkowska J, Bucholc B, et al. HBV genotypes among patients with chronic hepatitis B in the area of central Poland. Przegl Epidemiol 2006; 60: 555-561.

14. Stepień M, Czarkowski MP. Hepatitis B in Poland in 2011. Przegl Epidemiol 2013; 67: 239-245, 349-352.

15. Chan HL, Hui AY, Wong ML, et al. Genotype C hepatitis B virus infection is associated with an increased risk of hepatocellular carcinoma. Gut 2004; 53: 1494-1498.

16. Massoumi H, Martin P, Tan HH. Management of chronic hepatitis B. Eur J Gastroenterol Hepatol 2011; 23: 642-650.

17. Yuen MF, Tanaka Y, Shinkai N, et al. Risk for hepatocellular carcinoma with respect to hepatitis B virus genotypes $B / C$, specific mutations of enhancer II/core promoter/precore regions and HBV DNA levels. Gut 2008; 57: 98-102.

18. McMahon BJ, Holck P, Bulkow L, et al. Serologic and clinical outcomes of 1536 Alaska Natives chronically infected with hepatitis B virus. Ann Intern Med 2001; 135: 759-768.

19. Lin CL, Kao JH. The clinical implications of hepatitis B virus genotype: Recent advances. J Gastroenterol Hepatol 2011; 26 Suppl 1: 123-130.

20. Chien RN, Yeh CT, Tsai SL, et al. Determinants for sustained HBeAg response to lamivudine therapy. Hepatology 2003; 38: 1267-1273.
21. Wiegand J, Hasenclever D, Tillmann HL. Should treatment of hepatitis B depend on hepatitis B virus genotypes? A hypothesis generated from anexplorative analysis of published evidence. Antivir Ther 2008; 13: 211-220. 